\title{
Technology Transfer and Business Partnerships in BRICS: Development, Integration and Industrialisation
}

\author{
Zandi Lesame \\ Department of Communication Science, University of South Africa \\ Lesamnc@unisa.ac.za
}

\section{Doi:10.5901/mjss.2014.v5n7p284}

\begin{abstract}
South Africa joined the Brazil, Russia, India and China (BRIC) group of emerging economies in 2010. The group subsequently became known as BRICS. The group hosts summits to seek common ground on areas of importance and convergence for these major economies. This paper is descriptive and analytic in nature, providing background on economic relations and inequalities existing between the BRICS countries. It also provides details of the economic deliberations and partnerships agreed upon and concluded at the 5th BRICS Summit held in Durban South Africa. The research methodology applied to collect data and information about this topic is qualitative in nature, analysis content published about the summit in mass and online media and also a semiotic analysis of interviews broadcast on national television where government and business officials involved with BRICS commented on and abou the summit. These processes involve the analyses of secondary as a form of data collection. Data analysis involved identification of discussion themes raised by these officials in the data gathered, a discussion and commentary on the issues raised, and an interpretation of these issues by making use of international relations theories. This paper also compares the South African economic indicators and the status of the country to those of the other BRICS nations.
\end{abstract}

Keywords: development, technology, business partnerships, integration, industrialisation, technology transfer

\section{Introduction}

Currently, much of South Africa's positioning on the world stage is informed by global partnerships and developments such as the African Renaissance and global South-South multilateralism (as in G20) as well as North-South cooperation (as in BRICS and IBSA (India, Brazil and South Africa). This article examines the position occupied by South Africa in BRICS, evaluates the role played by South Africa in African development resulting from the association with the BRIC countries and considers South Africa's strategic value to BRICS.

The formation of BRICS represents the evolution of the international system toward a more international order. Several reasons for the formation of BRICS have been suggested. First, to an extent, BRICS could be viewed as a default outcome of the failure of the Group of 8 (G8) to incorporate some emerging economies such as India, Brazil and South Africa into the developed world of nations, since these developing countries play a significant role in promoting the development of the poorer countries, especially in the African continent. "Central to the BRICS endeavour is the desire to forge a developing country group capable of resisting the dominance" of the G8 developed countries in global affairs (Draper, 2013).

The BRICS group is as much a symbol as it is a concrete establishment (Freemantle, 2013). Emerging as it did during the global economic downturn in 2009; the then BRIC economies leveraged the opportunity to promote the robustness of their individual economies and their collective growth economically, just as the developed world was experiencing the downturn. The formation of the BRIC group represents a shift in the global political economy, global institutions and with regard to global governance issues as emerging economies merge to find solutions for the economic challenges affecting countries of the South. This paper explores these issues and views the role of South Africa as being critical as South Africa is widely regarded in the African shores as a gateway to African development. South Africa is also a representative of Africa in the BRICS group (Fabricius, 2013). The South African ruling party, the African National Congress (ANC), welcomed South Africa's membership to BRICS and the development of the BRICS Development Bank stating that BRICS is critical for developing nations (Mail \& Guardian, 2013). 


\section{Background on South Africa's Position in BRICS}

South Africa joined the Brazil, Russia, India and China (BRIC) group of emerging economies in 2010 (Yavuz, 2012; Lund, 2013). Some economic analysts and commentators, such as "Jim O'Neill, the retired Goldman Sachs executive who is credited for having coined the acronym "BRICS" to refer to the fast-growing emerging markets, have questioned whether South Africa should in fact be a member of BRICS, arguing that, relative to other BRICS countries, the South African economy is too small (as some cartoonist have depicted this in cartoons - see Figures 1 and 2 respectively), its growth is sluggish and its population "smallest" (Radebe 2013) to qualify as a member of this grouping of fast-growing emerging markets" (Fabricius \& Gumede, 2013). Furthermore, Fabricius and Gumede (2013) dismiss critiques such as O'Neill's, stating that it would be practically impossible to exclude South Africa in efforts aimed at African development and taking into consideration that since the end of apartheid in 1994, the core strategy of the South Africa's foreign policy has been to lead Africa towards political stability and economic revival, in other words to bring about an "African Renaissance".

\section{Figure 1: Indian Prime Minister welcomes South African President Jacob at BRICS 2012}

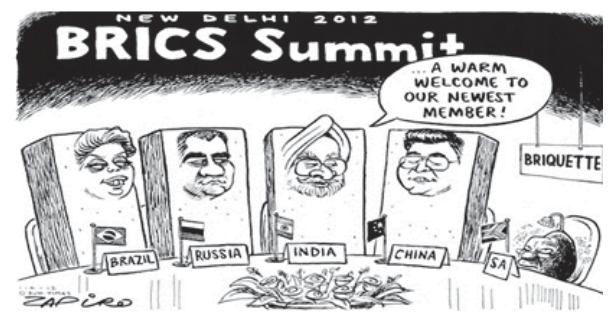

Figure 1, by South African cartoonist Jonathan Shapiro, known as Zapiro (2013a) depicts the picture of the presidents of the BRICS nations in 2010, Brazil President Dilma Rousseff, former Russian president Dmitry Medvedev, Indian Prime Minister Manmohan Singh, former Chinese president Hu Jintao and South African President Jacob Zuma. In the cartoon, the Indian Prime Minister Singh welcomes South African president Jacob Zuma, whose picture is compressed to indicate the South African economy regarded as small and also the geographic area of South Africa which is miniature (in geographic, technological innovation and economic terms) compared to China and India for instance. South Africa is described as a "briquette" than a BRIC because it ranks significantly lower in population and GDP than the BRIC nations (Smith, 2013). These lower population and GDP levels, some have argued, do not make South Africa fit to be a part of BRICS but others such as South African Minister of International Relations Nkoana-Mashabane (2013) and President Zuma (2013) firmly disagree with that view, arguing that GDP levels are not the only criteria that determine the investment potential and economic appeal of a country

Figure 2: "Zuma having car trouble during BRICS Summit" (Zapiro, 2013b)

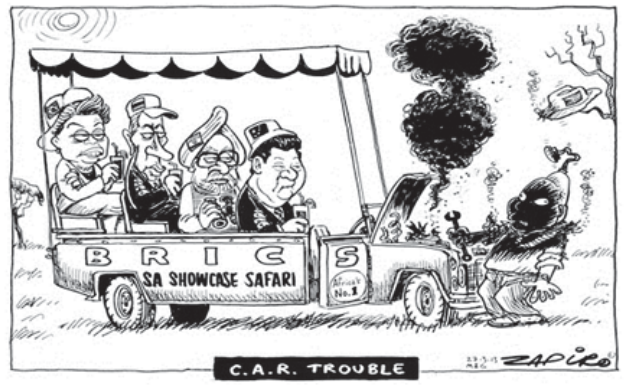

Source of Figure 2: Shapiro (Zapiro, 2013b)

Figure 2 depicts the 2013 BRICS Summit held in South Africa, depicted as a "SA Showcase Safari". Safari means a tour of the wild side of Africa, or tour of the natural resorts. The door of the "car" (indicated as being South Africa) opens up to 
indicate that South Africa has opened its doors to welcome BRIC nations even though South Africa as a country is not moving ahead as this car has ground to a halt due to "trouble", which could be interpreted to mean economic development which is slow compared to those of the BRIC countries. Also, during this period, South Africa had "trouble" regarding South African soldiers who died at war in the Central African Republic (CAR).

The South African "African Renaissance" policy is most evident in the famous speech, "I am an African" by the former state president of South Africa, Thabo Mbeki (1996). This speech promoted African identity and unity. Another argument in support of South Africa's inclusion in BRICS is that South Africa is also an economic leader on the African continent and, therefore, doing business with South Africa is an economic viable option for any country that desires to enter the African market (Mbeki, 1995 \& 2002; Fabricius \& Gumede, 2013). South African Minister of Finance Gordhan (2013) announced at the BRICS Summit that there are several measures that have been taken by BRICS to stimulate cross-border trade and investment (Lund, 2013). These measures have increased South African trade with BRIC rapidly over the past decade, between South Africa and China trade growing by 32 per cent in 2012; with India-South Africa trade growing by 25 per cent, and South Africa-Brazil growing by 20 per cent. South African exports to China grew by 46 per cent while exports to India grew by 20 per cent, exports to Brazil grew by 14 per cent and those to Russia grew by seven (7) per cent (Lund, 2013). Investment in South Africa has grown beyond investing in natural resources but interest from other countries is in other fields including software development (in the case of India as India leads in this field) as well as technology transfer and electronics skills training in the case of China (Mnyandu, 2013); aviation in the case of Russia (and Brazil in future) (Yavuz, 2013); automobiles (with South African cars exported to China, according to Ncapayi, of the South African Department of Trade and Industry, in Lund (2013), ceramics, renewable energy and the financial services sector.

International relations in BRICS continue to improve, as the next section explores this issue further.

\section{International Relations in BRICS and BRICS Contribution to the World Economy}

International relations theory that best describes the economic relations existing between the BRICS emerging economies are the pluralism or integration theory and realpolitik. An emerging economy is a concept that is used by academics and economists "as recognition of the rising, primarily economic, influence of a nation - or union of nations which has steadily increased their presence in global affairs" (Emerging power - Wikipedia, 2013). A major theoretical issue for scholars in international relations is whether inter-state relations illustrate the existence and continuation of realpolitik (the pursuit and/or maintenance of self-interest by nation-states) or whether those relations demonstrate a trend toward international integration, cooperation and harmonisation. South African leaders such as President Zuma (2013), the South African Minister of International Relations, Nkoana-Mashabane (2013), and leaders of the BRIC group, have stated that BRICS represents economic and political cooperation among the emerging economies and does not represent realpolitik.

\subsection{Realpolitik and integration theories}

The BRICS countries came together after the 2008 financial crisis as an alternative to the Western and mostly United States (US) dominated financial institutions (New Tang Dynasty/NTD TV on China 2013). Together, the BRICS group "want more equal institutions that will give better aid to developing countries and meet the demands of the $21^{\text {st }}$ century" (ibid.). Together, the five countries make up 40 per cent of the world's population and roughly 25 per cent of global Gross Domestic Product (GDP). Curnow (2013) describes the BRICS group as "economic powerhouses" which have "common interests", and focused on "rebuilding the world order brick by brick". BRICS relationships vary, but trade is key in the countries' relationship (Lund 2013). The South African Trade and Industry Minister, Rob Davies, enthused at the BRICS Durban Summit that the "BRICS bloc is championing a new paradigm for economic cooperation" (Davies 2013, in Lund 2013:30). For example, South African aviation company, Denel, has entered into business contracts with Russian helicopter companies for continent wide maintenance of Russian helicopters (Kgobe 2013 in Curnow, 2013).

South African economist Ballim, (in Curnow, 2013), states that BRICS countries a "political entity" with "common interests" that bring them together that they want to find solutions to, such as "climate change, global trade and currency wars". Furthermore, Lund (2013) states that the combined economic weight of BRICS cannot be underestimated because they constitute close to a fifth of global GDP, estimated at US\$13.7 trillion, combined foreign reserves estimated at US $\$ 4.4$ trillion, and 17 per cent of the world trade. The size of many of the BRICS economies leaves a huge amount of room for growth (Joubert 2013, in Lund 2013:35). Geographically, China and India are very large countries with the highest population figures in the world while the South African population was estimated at 52 million by the 2011 South 
African Statistical Review (Statistics South Africa, 2011).

The economic and political relations between the BRICs nations, explored in this section, demonstrate an integrative or pluralistic approach to international relations. The South African government's view of its role in BRICS could be viewed as voluntary. It also seeks international economic cooperation with the BRIC countries with the main purpose of building productive business partnerships for technological advancement and industrialisation of South Africa and other African countries. This could also be viewed as a neoliberal stance towards international relations. Zacher and Sutton (1996) broadly examine developments in the international relations regime with a view to understanding whether they are based on mutual interests among all participating states, in other words, a "neoliberal" approach (akin to the integration theory) or whether they focus on the interests and power of a dominant state or small group of powerful states, that is to say, a "neorealist" view (akin to realpolitik). According to Mosco (1988), pluralists believe that non-state actors are important entities in international relations that cannot be ignored. International cooperation in international telecommunications is necessary in the era of the convergence of technologies and increasing international relations. International cooperation's common theme is that states enter into voluntary agreements that in one way or another inform their domestic policies. These agreements are generally detailed and established mechanisms for dispute resolution. South Africa is also an emerging economy which promotes relations and bridged economic spaces between developed and less developed countries.

Pluralists hold the view that power is situational, that it operates in specific circumstances over specific issues (Zacher \& Sutton, 1996). For example, the BRICS agenda of international relations is vast, globalist and pluralist in nature, spreading from economics to social or welfare (health and education improvement) issues to environmental concerns such as energy saving. As an arena of international cooperation, it is fair to say that most decisions within BRICS, so far, are based on the pluralist idea of basing decisions on discussion of issues among member countries and basing resolutions on mutual interest. It is better to base decisions on mutual agreement than on force or power. Pluralist theories argue for more cooperation and interdependence between nations and regions of the world.

We live in the era of globalisation where ideas, activities and products of one or more countries spread over to other countries and are adopted in those countries.

Some critics, however, have alluded to the fact that China dominates the other BRICS countries (Lund, 2013) see Figure 3, which indicates that there is more trade with China, by the BRICS countries than there is trade with the other BRICS countries. Figure 3 also indicates that South Africa has far less trade with the other BRICS countries as the investment figures in Figure 3 indicate. Political relations between Russia and South Africa were reported as improving in media, after Russian President Putin referred to South African President Zuma as "champion of small nations" at the G20 summit in Russia (du Plessis, 2013: 8). The head of the Organisation for Economic Cooperation and Development (OECD) declared that the cooperation amongst the BRICS countries represented a "new paradigm", reflecting a shift in economic power away from the West (Tran, 2013). Furthermore, Desai (2013:1) is of the view that the "BRICS countries have a mortar that binds them, which is their common experience, and rejection, of the development model of the past several decades and the western-dominated IMF and World Bank that still advocate it". BRICS countries, according to Desai (2013) have long called for reform of the IFM and the World Bank only to meet with resistance. Rather than waiting for change in these major global financial institutions and more representation of developing countries in the IMF and the World Bank, BRICS countries decided to act and establish a bank that will assist towards faster development of emerging economies. The BRICS bank is expected to be operational by 2015.

Figure 3: Intra-BRICS trade

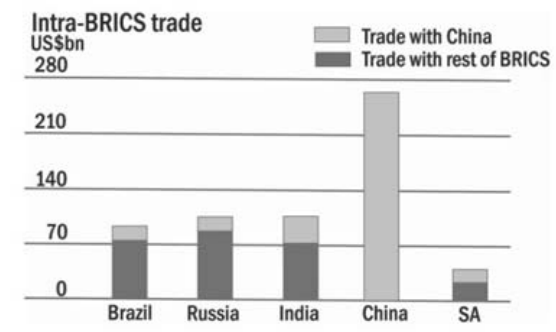

Source of Figure 3: Lund $(2013,30)$, reproduced by Wigston (2013); permission to reproduce granted by the Avusa Syndication (Kgaphola, 2013) 
Other sceptics of the unequal trade relations between the BRICS countries have cautioned that China could even recolonialise Africa as the Chinese investment in Africa has increased substantially over the past few years. Gumede (2013a) cautioned that while Africa needed economic support from China, it is also in the best interest of Africa to ensure that China's economic participation in and support of African development do not translate to realpolitik. This line of argument originates from the fact that China is viewed as one of the major economic investors in Africa and African business partners. On a state visit to South Africa in June 2013, the American president, Barack Obama, was asked about how he viewed the increasing number of Chinese business partnerships with African countries. President Obama (2013a; 2013b) responded that America supported business partnerships with other countries and saw "no threat" in African countries entering into business transactions with other countries (Mason \& Felsenthal, 2013; Reuters, 2013). However, President Obama, speaking at the University of Johannesburg in Soweto, South Africa, cautioned that African countries should ensure that such partnerships "benefit the African countries" and the African people (eNCA, 2013; South African Broadcasting Corporation, 2013). In another forum, Obama accused China of not benefitting Africa (Daily Nation, 2013). This Obama outlook, suggests that China is viewed by some as having a potential to engage in realpolitik in its quest to advance Chinese business interests in Africa.

Realpolitik means the exercise of power over others, while advancing national interests (Viotti \& Kauppi, 1999). Realpolitik is based on four assumptions (Viotti \& Kauppi, 1999), which are the following:

- First, states are the principal actors or most important actors and realists proceed from the premise that only states are key actors on the world stage that seek to maximise their own interests (Viotti \& Kauppi, 1999).While advancing self-interest, moral values are not the key guidelines in the realism paradigm. In the case of BRICS, states are the principal actors involved in political and business cooperation, but the political leaders are not the only major actors in BRICS councils and partnerships. Though the states are dominant role-players, they are not the key actors; some non-state actors in BRICS include academic and business leaders and billionaires (such as South African billionaire Patrice Motsepe who chairs the BRICS Business Council), technology manufacturers, business corporations and technology user groups. This pluralist view or a multi-stakeholder approach to development and international relations is more apparent in BRICS activities rather than realpolitik.

- Second, realists argue that the state is a unitary actor. "It is a unitary actor in that one policy at any given time, on any particular issue is held." As stated in bullet 1 above, states are not the only major actors at BRICS, but they are role players that play a significant role in national development and are active participants at BRICS forums and summits. Business also plays a crucial role in assisting BRICS to achieve its goals.

- Third, following from the above-mentioned assumptions, the state is essentially a rational actor. The state is seen as a rational actor because it ranks its preferences, maximising benefits and minimising costs. There are many actors in BRICS that design development projects and strategies aimed at building key infrastructure which is absent in Africa. One of the major economic projects is the establishment of the BRICS cable (in Figure 4) to facilitate and improve communication capacity between the BRICS nations. The establishment of the BRICS cable is more of an economic than a political decision.

- Fourth, realists assume that within the hierarchy of international issues, national security usually tops the list. Power is a key concept in the context of conflicts between state actors and the resolution of disputes among affected parties. Realists believe that military security or strategic issues can be viewed as high politics, whereas economic and social issues are viewed as less important or low politics. The BRICS group focuses more on economic development, unemployment reduction and job creation initiatives rather than on security concerns. These four factors, therefore, place BRICS within the international relations realm of cooperation and mutual economic development and are not indicators of realpolitik between the BRICS member countries. There has been no tangible evidence, thus far, that China is dominating the other four BRICS members.

What has been established though is that economically, China is the most powerful country in the BRICS group. In this regard, Gumede $(2013 \mathrm{~b}, 1)$ states that

its \$3.2 trillion foreign exchange reserves are three times bigger than those of the four other BRICS countries combined. This naturally brings an imbalance in power in favour of China. The sustainability of the BRICS alliance will heavily depend on whether the Chinese dragon, will use its financial muscle to force its way on issues.

Gumede (2013b) is also of the view that domestic growth policies in one partner has often caused economic imbalances in the economies of other BRICS partners and that China is at the centre of most of the complaints. Policymakers in South Africa and India, for example, have complained that China keeps its official currency, the renminbi, artificially undervalued to help boost Chinese exports and so power its industrialisation and growth and that this policy is 
causing imbalances in the economies of the BRICS partners. Another criticism is that the cheap value of the Chinese currency is "hurting the South African manufacturing sector", while "Brazil's Finance Minister, Guido Mantega, criticized China's undervalued currency as one of the distortions in world markets which is undermining the stability of the global economy" (Gumede, 2013b, 1). However, at the April 2011 BRICS meeting, assistant Chinese Foreign Minister, Wu Hailong, protected the China policy against attack stating that the "renminbi's exchange rate is not on the agenda for discussion" (ibid.). Chinese imports have been described as "cheap", and are also described as having hit the South African manufacturing sector hard and counteracted the plan of the South African government to revive this sector (Lund, 2103). However, Bruce (2013) recommends to South Africa that what is more important in understand the China-South Africa trade relations is not to criticise how China does business, but what is crucial is what South Africa could learn from how China does business. For example, Bruce (2013) is of the view that South Africa could learn from China, how to get rid of "incompetence and corruption" in government in order to improve the economic performance of South Africa.

\section{The Strategic Value Added by South Africa to BRICS}

The South African Minister of International Relations and Cooperation, Nkoana-Mashabane (2013) has been promoting the journey of South Africa to BRICS and spearheading active participation of South Africa in BRICS. NkoanaMashabane (2013), argues that South Africa adds the following strategic value to BRICS:

- South Africa has always been at the forefront with regard to promoting inclusivity in business and other associations and more equitable participation of emerging and developing economies in the world system of markets;

- South Africa enjoys global recognition as a regional economic player and plays a critical role in global institutions such as the International Monetary Fund (IMF), World Bank, African Union (AU), Group of 20 (G20) and the United Nations (UN) where it represents the African voice. Also in the African region, South Africa plays a significant role as an economic force and peacemaker in countries such as Sudan and others (Nkoana-Mashabane, 2013);

- the Minister of Trade and Industry, Davies (2012), stated that trade between South Africa and the BRIC countries grew by 25 per cent in 2011, thus reducing the negative trade balance by billions of Rand (South African currency); and that

South Africa's financial development, sophistication and financial expertise have been globally recognised by the World Economic Forum's 2011/12 Global Competitiveness Index and was ranked in fourth place globally in that measure.

These positive South African values and also the fact that South Africa is rich in mineral wealth, or put South Africa in a favourable position as an investment destination and as a point of entry into the African business market. The South African government also views BRICS as the "G8 of the South" (Fabricius, 2013), which indicates that South Africa is viewed as the economic powerhouse of Africa and could be used as a trade entry in Africa.

\section{BRICS Economic Spin-Offs and Lessons for South Africa in BRICS}

The most concrete outcome of the summit was the decision to establish a BRICS bank, which is conceptualised as a development bank which will channel some of the vast reserves of the bigger BRICS countries - estimated at about US\$4 trillion (South African Rand 42 trillion) - into development projects, mainly infrastructure development (Fabricius, 2013). At the 5th BRICS Summit the infrastructure financing needs of the BRICS countries were also estimated to be at US $\$ 4.5$ trillion over five years. A second critical development arising from the 5th BRICS Summit is the signing of the eThekwini (Zulu language name for the city of Durban, South Africa) Declaration. In so doing the countries have committed themselves to the establishment of a BRICS business council (Fakir, 2013) to facilitate business partnerships between the BRICS countries and the creation of a research "think tank" whose role is viewed as that identifying business and job creation areas, such as infrastructure, that BRICS should prioritise and develop steadfastly. This "think-tank" will also advise South Africa on technology transfer issues, especially in infrastructure development and education advancement projects. Some of the educational projects signed at the summit include an education and literacy improvement project, which involves recruiting students from South Africa to study in the field of technology and earn degrees in China. The development of the BRICS cable is another major economic spin-off of the BRICS 2013 Summit as it is expected that the planned cable will optimise business communication between the BRICS members. The envisioned route of the BRICS cable can be seen in Figure 4. 
Figure 4: BRICS Cable

Available at: http://bricscable.com

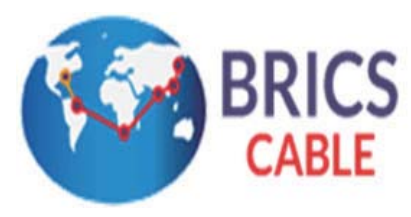

Additionally, South Africa would do well to remember and admire the B in BRICS and what it could learn from Brazil in terms of how to reduce the high unemployment rate and improve national gross domestic product (GDP) (Lewis, 2013).This is especially important with regard to reducing the high unemployment rate in South Africa, which was reported to be at 40 per cent in 2011. The Quarterly Labour Force Survey of the first quarter of 2013 indicated that unemployment has risen to 25 per cent and that this figure may rise to 40 per cent if discouraged job seekers are included (Khuzwayo, 2013). Brazil decreased her unemployment rate from a high 13 per cent in 2003 to a low 4.6 per cent in December 2012 and it increased the standards of living over the past ten years under the government of Lula da Silva and the Workers Party (Lewis, 2013). In contrast, the South African unemployment rate has been on the rise for the past few years and the South African Network Survey (2013) conducted by Network Society South Africa, established that South Africa is "the most connected country" in Africa, but it has "only the sixth-fastest growth rate". The World Economic Forum (WEF) in its Global Information Technology (IT) Report (2013, in South Africa E-Institute e-Skills Newsletter Edition 13), attributes this limited economic growth and lack of growth in information and communication technology (ICT) facilities to the perception of a lack of a clear government ICT policy strategy for South Africa, coupled with deficiencies in the education sector (South Africa is rated 102nd in the world by the WEF in educational development - as depicted in Table 1). These findings reveal the prevailing factors that impact negatively on the growth of the national ICT sector, among other sectors, which is a key factor in national economic development. It is expected, therefore, that South Africa will acquire crucial development and economic lessons from its BRICS counterparts, more especially China, which is viewed as the most economically powerful of the five.

Table 1: BRICS 2013 ICT environment, readiness, and usage and impact sub-indices

\begin{tabular}{|l|c|c|c|c|c|}
\hline \multicolumn{1}{|c|}{ Overall\& Sub-index/Pillars (BRICS2013) } & SA & Brazil & Russia & India & China \\
\hline Overall & 70 & 60 & 54 & 68 & 58 \\
\hline A. Environment sub-index & 33 & 107 & 102 & 85 & 71 \\
\hline 1.Political \& regulatory environment & 21 & 78 & 108 & 75 & 56 \\
\hline 2.Business \& innovation environment & 55 & 126 & 90 & 90 & 105 \\
\hline B. Readiness sub-index & 95 & 74 & 32 & 68 & 66 \\
\hline 3.Infrastructure \&digital content & 59 & 62 & 43 & 111 & 83 \\
\hline 4.Affordability & 104 & 76 & 18 & 1 & 40 \\
\hline 5.Skills & 102 & 91 & 61 & 95 & 53 \\
\hline C. Usage sub-index & 72 & 44 & 56 & 81 & 58 \\
\hline 6.Individual usage & 81 & 58 & 45 & 121 & 83 \\
\hline 7.Business usage & 33 & 34 & 95 & 45 & 35 \\
\hline 8.Government usage & 102 & 48 & 74 & 40 & 38 \\
\hline D. Impact sub-index & 92 & 50 & 53 & 56 & 55 \\
\hline 9.Economic impacts & 51 & 50 & 54 & 43 & 83 \\
\hline 10.Social impacts & 112 & 48 & 60 & 73 & 42 \\
\hline
\end{tabular}

Source: South African e-Skills Institute Newsletter (2013, Edition 13)

Table 1 indicates that the South African ICT regulatory environment is more advanced than that of the other BRICS countries. However, the ICT policy has not been implemented successfully by the mandated governmental bodies, which has affected ICT infrastructure development negatively. Table 1 also shows that ICT services are most affordable in India and most expensive in South Africa, which has also negatively affected usage as most citizens are unable to afford this technology. Moreover, South Africa has a shortage of ICT skills; it is rated 102th in the world, which is worse compared to the other BRICS countries. The South African government's use of ICT is also the lowest (at 102) compared to the other 
governments of the BRICS countries. The social impact of ICT on South Africans has also been less than on Brazilians, Russians, Indians and Chinese citizens.

\section{Conclusions}

South Africa joined the Brazil, Russia, India and China (BRIC) group of emerging economies in 2010, with the aim of improving the economic status of South Africa and that of other African countries by promoting political and economic relations with BRIC nations. South African leaders such as President Zuma and the Minister of International Relations, Nkoana-Mashabane, and also the BRIC leaders, have stated that BRICS represents economic and political cooperation between the emerging economies and does not mean domination of one economic nation by another. The South African Minister of Trade and Industry (Davies, 2013) has also stated that the inclusion of South Africa in the BRICS group of emerging economies has improved South Africa's ability to act as a focal entry point for African investment and development at a time when the continent's economies have undertaken to break down trade down barriers and integrate their markets. South Africa has also, in the past few years, championed South-South cooperation and North-South dialogue. At the 5th BRICS Summit in South Africa, March 2013, the South African president Zuma, articluated that the summit had resulted in more business partnerships between governments and private sector companies which will bring greater prosperity and progress to the people of South Africa. Membership to the BRICS group and participation in the 5th BRICS Summit is viewed as an fortuitous economic opportunity for South Africa, since it would enable South Africa, which is the least developed among the BRICS countries, to learn from the other BRICS countries and speed up development which has been stagnant from 1994 to 2014 (20 years of democracy).

This paper briefly compared South Africa to the other BRIC nations in terms of economic indicators and status with the main purpose of pointing out the hard facts and shortcomings about South Africa, highlighting the leadership and developmental challenges that South Africa has to surmount in order to achieve the developmental heights that have been achieved by her BRIC counterparts which are developmentally more advanced than South Africa. One of these challenges is that the government in power has to eliminate corruption within its ranks and focus on providing public services to citizens, and communications technology and services, e.g., an affordable broadband network for most citizens, being one of those services. The governing political party has admitted that corruption exists within its government (South African Press Association/SAPA, 2014), but have not yet stated how the party plans to eliminate such corrupt tendencies since they continue to paralyze and destabilize South Africa. Civil society, on the other hand, is getting impatient with corruption since is a wasteful expenditure which diverts public funds to self-enrichment initiatives which delay the delivery of public services to members of the public.

This article is descriptive and analytic in nature, providing background information about economic relations and inequalities that exist between the BRICS countries. It also detailed the economic deliberations and partnerships agreed upon and concluded at the 5th BRICS Summit in Durban and the eThekwini Declaration which was signed by all the parties at the end of the summit. These partnerships include the establishment of the BRICS Development bank, BRICS Marine Cable and the BRICS Business Council. It is expected that these business projects, and others which are likely to arise as a result of future BRICS meetings, will assist South Africa in its endeavour to improve issues of governance, including getting rid of corruption, incompetence and lack of public service delivery in government departments while these departments, such as those mentioned in this article, are doing business with government and business officials from BRIC countries. Arising trade and political challenges and frictions are solved through negotiation or what Ncapayi (in Lund, 2013) calls "engagement", or, what Carrim (2013 in Lund, 2013) calls "a win-win solution". Additionally, manufacturing initiatives between the BRICS group are regarded as being "complementary" instead of being "competitive" (Ncapayi in Lund, 2013). This complementary nature of decision-making could be useful in sectors such as the automobile sector where one country could manufacture some car parts while another country manufactures other parts and duplication could be avoided. This also ensures job creation in all the countries instead of in one country. Proposed infrastructure development projects could also assist South Africa with regard to the creation of job opportunities for the unemployed, thus reducing the high unemployment rate. Education and health promotion projects between China and South Africa are also intended to improve poor education levels in South Africa. Against this background, there are visible economic benefits that South Africa can derive from her association with the BRICS group and these benefits can be extended to other African countries through further business partnerships, mergers, acquisitions and empowerment projects. BRICS also represents less dependence of emerging economies on the developed, rich countries in future, as analysed and predicted by television station commentators and presenters, economists on YouTube and other media, as well as economy analysts forecasting the role and contribution of BRICS in the world economy. 


\section{References}

BRICS Cable. 2013. Accessed on 07-07-2013

Bruce, P. 2013. Thick end of the wedge: welcome to our new leader. Business Day Live. http://www.bdlive.co.za/opinion/columnists /2013/03/25/thick-end-of-the-wedge-welcome... Retrieved 02-05-2013

Cohen, T. 2013. BRICS may work in good times, but in crisis times? 25 March:1-6. http://www.bdlive.co.za/opinion/columnists/2013 /03/25/brics-may-work-in-good-times-b Retrieved 02-05-2013

Curnow, R. 2013. BRICS countries meet in South Africa. CNN YouTube video http://www.cnn.com/video/ Retrieved 10-08-2013

Davies, R. 2012. South Africa in the BRICS group of emerging economies. Cape Town: South African Parliament.

Desai, R. 2013. The BRICS are building a challenge to western economic supremacy. The Guardian. April 2: 1-3. Available online at: http://www.theguardian.com/commentisfree/2013/apr/02/brics-challenge-western-sup... Retrieved 28-08-2013

Draper, P. 2013. Can member states develop a meaningful trade agenda? Business Day 3 April: 1.

Du Plessis, C. 2013. Zuma champion of the "small nations". City Press. September 8: 8.

Emerging Power - Wikipedia, the free encyclopaedia. 2013. http://en.wikipedia.org/wiki/Emerging_Powers Retrieved 02-80-2013

eNews Television Channel. 2013. Live Broadcast of President Barack Obama State Visit Speech in South Africa. Pretoria: Union Buildings. June 29.

Fabricius, P. 2013. Rude awakening for SA as new bank reveals realities of tough international diplomacy. Business Report. http://www.safpi.org/newss/article/2013/south-african-commentaries-brics-summit-outco... Retrieved 17-07-2013

Fabricius, P. \& Gumede, W. 2013. We should jealously defend our economic interests in emerging market groups. Business Report Mobile. Is South Africa building the right Brics? 31 March:1-5. http://m.br.co.za/article/view/e/1.1493851 Retrieved 08-05-2013

Fakir, S. 2013. The BRICS Bank and world dominance: how real is this? South African Information Civil Society Information Service. http://www.safpi.org/newss/article/2013/south-african-commentaries-brics-summit-outco... Retrieved 12-07-2013

Freemantle, S. 2013. Supportive pillars added to a nebulous grouping. African arguments. http://www.safpi.org/newss/article/2013/southafrican-commentaries-brics-summit-outco... Retrieved 08-07-2013

Gumede, W. 2013a. Complicated relationship holds Brics back. Mail\&Guardian 22 March 8 http.mg.co.za/article/2013-03-22 Accessed on 04-06-2013

Gumede, W. 2013b. Africa: challenges of the Brics 28 March: 1-5. http://allafrica.com/stories/201303290959.html Retrieved 10-07-2013

Kgaphola, P. 2013. Re-Request for permission. E-Mail to Lesame N C. Johannesburg: Avusa Syndication. September 04.

Khuzwayo, W. 2013. SA's unemployed ranks swell to 25\%. Pretoria News Business Report 7 May:13.

Lewis, J. 2013. South Africa should learn from Brazil's Bolsa Familia. AllAfrica.com http://allafrica.com/stories/201304040319.html Retrieved 10-07-2013

Lund, T. 2013. Trading up: The Brics bloc wants deeper trade and investment ties to underpin its alliance. Financial Mail. March 15 March 20: 30-37.

Mail \& Guardian. 2013. ANC: Brics is critical for developing nations. http://mg.co.za/article/2013-03-25-anc-brics-is-critical-in-developingnations Retrieved 17=-7-2013

Mandela, N. 1995. Towards a world-wide information society. Intermedia 23(6):46-47.

Mbeki, T. 1995. Deputy President Thabo Mbeki's address to the G8 countries. Brussels: G8 Economic Summit.

Mbeki, T. 1996. Presidential Speech: I am an African. Cape Town: South African Parliament. May 8. Mbeki, T. 2002. New economic partnership for African development (NEPAD). Ottawa: G8 Summit.

Mnyandu, E. 2013. First business council helps cement BRICS: Delegates commit to practical development partnerships. Pretoria News Business Report August 21: 1.

Mosco, V. 1988. Toward a theory of the state and telecommunications policy. International telecommunications: what is price policy? Journal of Communication Winter:107-124.

New Tang Dynasty (NTD) on China. 2013. BRICS countries to establish Development Bank. YouTube video http://ntd.tv Retrieved on 10-08-2013

Nkoana-Mashabane, M. 2013. Media statement by the Minister of International Relations and Cooperation. April 4. Pretoria: South African Government Department of International Relations and Cooperation (DIRCO).

Obama, B. 2013a. Obama and Zuma press conference at the Union Buildings, Pretoria, and President Barack Obama addressing students at the University of the Witwatersrand, Johannesburg. June 29.

Obama, B. 2013b. Obama accuses China of not benefitting Africans. Africa - nation.co.ke http://www.nation.co.ke/news/africa /China+taking+more+from+Africa+than+it+gives... Retrieved 10-08-2013

Radebe, S. 2013. Zuma pushes for BRICS Bank. The New Age August 21: 15

Reuters. 2013. Barack Obama: No threat in China rivalry for Africa business. Pretoria News June 29. http://www.financialexpress.com Inews/barack-ob ama-no-threat-in-china-rivalry-for-a... Retrieved 10-08-2013

South African Press Association (SAPA). 2014. ANC to step up fight against corruption. January 25 http://www.mg.co.za/article/2015-0125-anc-to-fight-against-corruption-says-mantashe Retrieved on 26-01-2014

Shapiro (Zapiro), J. 2013a. New Delhi 2012 BRICS Summit. Cartoon Number 120401st http://www,zapiro.com/cartoon/778707-120401st Retrieved on 10-08-2013

Shapiro (Zapiro), J. 2013b. Zuma having CAR Trouble. Cartoon Number 130327mg http://www.zapiro.com/cartoon/1570536-130327mg Retrieved on 10-08-2013 
Smith, D. 2013. South Africa: more of a briquette than a BRIC? The Guardian March 23: 1-3. http://www.theguardian.com/world /2013/mar/24/south-africa-bric-developing-economy Retrieved on 12-08-2013

South African Broadcasting Corporation (SABC). 2013. Live Broadcast of President Barack Obama State Visit Speech in South Africa. Pretoria: Union Buildings. June 29.

South African Network Survey. 2013. City Press 19 May: 25.

Statistics South Africa. 2011. South African Demographic Survey. Pretoria: Statistics South Africa.

Tran, M. 2013. BRICS bank raises critical development questions, says OECD. The Guardian. April 9: 1-3. Available online at: http://www.theguardian.com/global-development/2013/apr/09/brics-bank-critical-que... Retrieved 28-08-2013

Viotti, PR \& Kauppi, MV. 1999. International relations theory: realism, pluralism, globalism. New York: Macmillan.

Wigston, DJ. 2013. Intra-BRICS trade.jpg. Pretoria: University of South Africa. E-Mail to Lesame N. September 10.

World Economic Forum (WEF) Global Information Technology (IT) Report. 2013. in e-Skills Newsletter. Pretoria: E-Skills Institute and Department of Communications. Edition 13:2)

Yavuz, F. 2013. BRICS Countries - Brazil, Russia, India, China and South Africa - Emerging economies. South Africa. YouTube video. Accessed on 08-07-2013

Zacher, M \& Sutton, BA. 1996. Governing global networks: international regimes for transportation and communications. Cambridge: Cambridge

Zimela, Z. 2013. SA to benefit from BRICS Summit. Business Day Live. http://www.bdlive.co.za/national/2013/03/27/sa-to-benefit-frombrics-summit Retrieved on 20-07-2013 